\title{
Development of acute kidney injury with massive granular casts and microscopic hematuria in patients with COVID-19: two case presentations with literature review
}

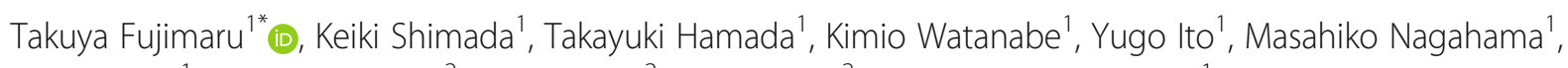
Fumika Taki ${ }^{1}$, Shutaro Isokawa², Toru Hifumi ${ }^{2}$, Norio Otani ${ }^{2}$ and Masaaki Nakayama ${ }^{1}$

\begin{abstract}
Background: Complications of acute kidney injury (AKI) are common in patients with coronavirus disease in 2019 (COVID-19). However, clinical characteristics of COVID-19-associated AKI are poorly described. We present two cases of severe COVID-19 patients with AKI.

Case presentation: A 77-year-old woman was suspected of having vancomycin-associated AKl, and a 45-year-old man was suspected of having heme pigment-induced AKI caused by rhabdomyolysis. The granular cast, which is known to be a valuable diagnostic tool for confirming the diagnosis of acute tubular necrosis, was detected in both patients at the onset of AKI. Interestingly, both patients also developed microscopic hematuria at the occurrence of AKI, and one patient had elevated D-dimer and low platelet levels simultaneously.

Conclusions: Some reports suggested that COVID-19-associated microangiopathy contributed to the kidney damage. Therefore, it is possible that our patients might have accompanied renal microangiopathy, and that this pathological background may have caused exaggerated tubular damage by vancomycin or heme pigment. The etiology of AKI in patients with COVID-19 is multifactorial. Superimposition of nephrotoxin(s) and virus-associate intra-renal microangiopathy may be a crucial trigger of kidney injury leading to severe AKI in COVID-19 patients. Therefore, in COVID-19 patients, risk factors for AKI should be taken into consideration to prevent its progression into severe AKI.
\end{abstract}

Keywords: COVID-19, Acute kidney injury, Vancomycin-induced acute kidney injury, Rhabdomyolysis, Microangiopathy, Urine sediment examination

\section{Background}

Severe acute respiratory syndrome coronavirus 2 (SARS$\mathrm{CoV}-2$ ) was identified to be the cause of a cluster of pneumonia cases in Wuhan, a city in the Hubei Province of China at the end of 2019. It rapidly spread to other provinces in China and around the world. In February 2020,

\footnotetext{
* Correspondence: fujitaku@luke.ac.jp

'Department of Nephrology, St. Luke's International Hospital, 9-1 Akashi-cho, Chuo-ku, Tokyo 104-8560, Japan

Full list of author information is available at the end of the article
}

the World Health Organization designated the disease COVID-19, which stands for coronavirus disease in 2019.

Besides severe acute respiratory syndrome, complications of acute kidney injury (AKI) are not uncommon in patients with COVID-19. A recent study of 5449 patients who were hospitalized with COVID-19 in New York revealed that $36.6 \%$ of patients developed AKI and 14.3\% required renal replacement therapy [1], and to note, AKI is significantly associated with in-hospital mortality in

(c) The Author(s). 2020 Open Access This article is licensed under a Creative Commons Attribution 4.0 International License, which permits use, sharing, adaptation, distribution and reproduction in any medium or format, as long as you give appropriate credit to the original author(s) and the source, provide a link to the Creative Commons licence, and indicate if changes were made. The images or other third party material in this article are included in the article's Creative Commons licence, unless indicated otherwise in a credit line to the material. If material is not included in the article's Creative Commons licence and your intended use is not permitted by statutory regulation or exceeds the permitted use, you will need to obtain permission directly from the copyright holder. To view a copy of this licence, visit http://creativecommons.org/licenses/by/4.0/ The Creative Commons Public Domain Dedication waiver (http://creativecommons.org/publicdomain/zero/1.0/) applies to the data made available in this article, unless otherwise stated in a credit line to the data. 
COVID-19 patients [1-4]. Therefore, it is of vital importance to prevent AKI development in this population.

In regard to the pathological mechanisms of AKI development in COVID-19, it is thought that the virus infection is directly linked with kidney injury. This is because angiotensin-converting enzyme 2 , a putative receptor for SARS-CoV-2, is expressed in the kidneys of humans [5]. However, clinical characteristics of COVID19-associated AKI are poorly described.

Herein, two cases are presented of severe COVID-19 patients with AKI. This report suggests the possible role of superimposition of nephrotoxin(s) and virus infectionassociated microangiopathy in the kidney for developing severe AKI in COVID-19 patients. This suggests that withholding nephrotoxic agents as much as possible may lessen the risk of AKI occurrence within a clinical setting.

\section{Case presentation}

\section{Patient 1 (Table 1)}

A 77-year-old woman was referred to our hospital suspected of COVID-19 with a 4-day history of dyspnea. Eight days prior to the admission, she had a fever, cough, and sore throat. Her son was diagnosed with COVID-19
2 days before her admission. She had no history of diabetes, hypertension, and/or chronic kidney disease. On the day of admission, she was alert with a body temperature $37.7^{\circ} \mathrm{C}$, blood pressure at $114 / 66 \mathrm{mmHg}$, heart rate at 66 per minute, respiration at 24 per minute, and oxygen saturation at 96\% (nasal cannula delivering oxygen $4.0 \mathrm{~L}$ per minute). The physical examination was unremarkable. The laboratory test revealed an increase in the C-reactive protein (CRP) level. The patient's renal and liver functions were normal. Using a dipstick urinalysis, $1+$ proteinuria and $1+$ hematuria were detected. Chest CT without contrast showed ground-glass opacities in bilateral lower lobes. Ceftriaxone and azithromycin were started. Her respiratory condition gradually deteriorated. The SARS-CoV-2 PCR test performed on the day of admission returned positive 2 days later. On the sixth day of admission, she was intubated and received mechanical ventilation, and piperacillin-tazobactam ( $4.5 \mathrm{~g}$ every $6 \mathrm{~h})$ and methylprednisolone $(120 \mathrm{mg} /$ day for 3 days) were started. On day 12, due to the possible superimposed infection with fever and increased white blood cell count, blood cultures were taken and vancomycin was administered (loading dose of $2 \mathrm{~g}$ and maintenance dose of $1 \mathrm{~g}$

Table 1 Physiological and laboratory data of patient 1

\begin{tabular}{|c|c|c|c|c|c|c|c|c|c|c|}
\hline Day of admission, days & 1 & 5 & 8 & 12 & 16 & 19 & 22 & 26 & 34 & 44 \\
\hline Day of illness, days & 8 & 12 & 15 & 19 & 23 & 26 & 29 & 33 & 41 & 51 \\
\hline \multicolumn{11}{|l|}{ Renal } \\
\hline $\mathrm{Cr}, \mathrm{mg} / \mathrm{dL}$ & 0.59 & 0.41 & 0.62 & 0.43 & 2.22 & 3.30 & 1.62 & 0.99 & 0.56 & 0.39 \\
\hline Urine volume, $\mathrm{ml} /$ day & N/A & 890 & 1775 & 1815 & 1320 & 2160 & 2515 & 2325 & 1230 & 1020 \\
\hline Serum BUN, mg/dL & 17.1 & 16.9 & 44.6 & 34.6 & 69.2 & 125.3 & 79.2 & 55.5 & 49.6 & 37.2 \\
\hline Body weight, kg & $55.0^{c}$ & 54.9 & 57.6 & 58.5 & 56.1 & 56.4 & 54.1 & 55.4 & $52.0^{e}$ & 48.4 \\
\hline Urine protein $^{a}$ & $1+$ & $\mathrm{N} / \mathrm{A}$ & $1+$ & $1+$ & $+/{ }^{d}$ & $+/-$ & None & $+/-$ & $1+$ & $+/-$ \\
\hline Urine occult blood ${ }^{a}$ & $1+$ & N/A & None & $+/-$ & $+/-$ & None & $+/-$ & None & $+/-$ & None \\
\hline Urine $\mathrm{RBC}$, /HPF & $\mathrm{N} / \mathrm{A}$ & N/A & $<1$ & $5-9$ & $30-49^{d}$ & $<1$ & $1-4$ & $1-4$ & N/A & None \\
\hline Granular cast ${ }^{\mathrm{b}}$ & N/A & N/A & None & None & $4+^{d}$ & None & None & $1+$ & N/A & None \\
\hline \multicolumn{11}{|l|}{ Respiratory } \\
\hline $\mathrm{O}_{2}$ Device & NC & MV & MV & MV & MV & MV & MV & MV & MV & VM \\
\hline $\mathrm{PaO}_{2} / \mathrm{FiO}_{2}$ ratio, $\mathrm{mmHg}$ & $\mathrm{N} / \mathrm{A}$ & 123 & 206 & 144 & 148 & 136 & 137 & 137 & 233 & 266 \\
\hline \multicolumn{11}{|l|}{ Immunology } \\
\hline WBC, /uL & $6800^{c}$ & 13200 & 13400 & 15800 & 14100 & 15400 & 10200 & 14000 & 13600 & 14000 \\
\hline Lymphocyte, /uL & $1200^{c}$ & 790 & 340 & 550 & 280 & 540 & 710 & 490 & 410 & 1190 \\
\hline $\mathrm{CRP}, \mathrm{mg} / \mathrm{dL}$ & 10.45 & 20.37 & 8.02 & 1.53 & 16.17 & 5.92 & 2.02 & 16.32 & 1.51 & 4.29 \\
\hline Platelet, $\times 10^{3} / \mathrm{uL}$ & 133 & 188 & 175 & 158 & 183 & 237 & 195 & 251 & 189 & 262 \\
\hline D-dimer, ug/mL & 1.0 & 6.3 & $>100$ & 28.5 & 24 & 9.8 & 12.2 & 10.4 & 11.9 & 3.5 \\
\hline
\end{tabular}

$\mathrm{Cr}$ Creatine, BUN Blood urea nitrogen, $\mathrm{RBC}$ Red blood cell, $\mathrm{HPF}$ High-power field, $V C M$ Vancomycin, Conc Concentration, $\mathrm{PaO}_{2}$ Partial pressure of oxygen, $\mathrm{FiO}_{2}$ Fraction of inspiratory oxygen, WBC White blood cell, CRP C-reactive protein, N/A Not available, NC Nasal cannula, MV Mechanical ventilation, VM Venturi mask ${ }^{\mathrm{a}}$ Data by dipstick

bData by microscopy

'Data of second day of admission

${ }^{\mathrm{d} D a t a}$ of 17 th day of admission

${ }^{\mathrm{e}}$ Data of 34th day of admission 
twice a day), but it was discontinued on hospital day 15 with negative blood cultures. On hospital day 16, favipiravir was started because of deterioration confirmed by chest CT scan without contrast. On the same day, serum creatinine had started to elevate (trough vancomycin concentration $26.75 \mathrm{ug} / \mathrm{mL}$ ), despite adequately maintained blood pressure with no clinical signs of hypotension and volume depletion. Urine microscopy detected massive granular casts and mild hematuria with no dysmorphic red blood cells (RBCs) (30-49 RBCs per high-power field $[\mathrm{RBCs} / \mathrm{HPF}])$ and a urine dipstick confirmed that there was no presence of proteinuria. The patient was suspected of vancomycin-associated acute tubular necrosis (ATN). Her respiratory condition remained unchanged; however, her serum creatinine level gradually decreased over the course of several days, with no appearance of granular casts and hematuria thereafter. She underwent tracheostomy on hospital day 26 , and mechanical ventilation was withdrawn on hospital day 44 .

\section{Patient 2 (Table 2)}

A 45-year-old man was referred to our hospital with severe respiratory failure and a 10-day history of dyspnea. $\mathrm{He}$ had no history of diabetes, hypertension, and/or chronic kidney disease. He was smoking one pack of cigarettes per day. On the day of admission, he was alert with a body temperature of $37.7^{\circ} \mathrm{C}$, blood pressure at $154 / 110 \mathrm{mmHg}$, heart rate at 106 per minute, respiration at 36 per minute, and oxygen saturation at $70 \%$ with reservoir mask. The laboratory test revealed an increased CRP level. His renal and liver functions were normal. Using a dipstick urinalysis, 1+ proteinuria was detected

Table 2 Physiological and laboratory data of patient 2

\begin{tabular}{|c|c|c|c|c|c|c|c|c|}
\hline Day of admission, days & 1 & 5 & 8 & 11 & 15 & 21 & 29 & 40 \\
\hline Day of illness, days & 10 & 14 & 17 & 20 & 24 & 30 & 38 & 49 \\
\hline \multicolumn{9}{|l|}{ Renal } \\
\hline Serum $\mathrm{Cr}, \mathrm{mg} / \mathrm{dL}$ & 0.96 & 1.05 & 1.82 & 4.92 & 8.03 & 4.35 & 1.58 & 0.86 \\
\hline Urine volume, $\mathrm{ml} /$ day & 1110 & 1680 & 1965 & 1125 & 2680 & 2860 & 3000 & N/A \\
\hline Serum BUN, mg/dL & 22.7 & 43.9 & 75.9 & 119 & 135.8 & 65.0 & 15.5 & 9.8 \\
\hline Body weight, kg & 71.7 & 71.9 & 71.1 & $72.8^{e}$ & 71.9 & $\mathrm{~N} / \mathrm{A}$ & 66.0 & $\mathrm{~N} / \mathrm{A}$ \\
\hline Urine color & straw & $\mathrm{N} / \mathrm{A}$ & brown & bloody & bloody & straw & straw & straw \\
\hline Urine protein $^{a}$ & $2+$ & $\mathrm{N} / \mathrm{A}$ & $2+$ & $3+$ & $2+$ & $+/-$ & None & None \\
\hline Urine occult blood ${ }^{a}$ & None & $\mathrm{N} / \mathrm{A}$ & $3+$ & $3+$ & $3+$ & $3+$ & None & None \\
\hline Urine RBC, /HPF & $\mathrm{N} / \mathrm{A}$ & $\mathrm{N} / \mathrm{A}$ & $1-4$ & $>50$ & $>50$ & $>50$ & None & None \\
\hline Granular cast $^{b}$ & $\mathrm{~N} / \mathrm{A}$ & $\mathrm{N} / \mathrm{A}$ & $4+$ & $5+$ & $4+$ & $1+$ & None & None \\
\hline Urine B2MG, ng/mL & N/A & $\mathrm{N} / \mathrm{A}$ & 4580 & $\mathrm{~N} / \mathrm{A}$ & $30322^{f}$ & 7374 & 608 & 478 \\
\hline Serum CK, U/L & 281 & $\mathrm{~N} / \mathrm{A}$ & 12901 & 79508 & 5547 & 1220 & 360 & 307 \\
\hline Urine myoglobin, ng/mL & $\mathrm{N} / \mathrm{A}$ & $\mathrm{N} / \mathrm{A}$ & 120000 & 95000 & $10000^{f}$ & $\mathrm{~N} / \mathrm{A}$ & $\mathrm{N} / \mathrm{A}$ & $\mathrm{N} / \mathrm{A}$ \\
\hline \multicolumn{9}{|l|}{ Respiratory } \\
\hline $\mathrm{O}_{2}$ Device & MV & MV & MV & $\mathrm{NC}$ & $\mathrm{NC}$ & $\mathrm{NC}$ & RA & RA \\
\hline $\mathrm{PaO}_{2} / \mathrm{FiO}_{2}$ ratio, $\mathrm{mmHg}$ & 211 & 288 & 315 & 382 & 403 & 425 & $\mathrm{~N} / \mathrm{A}$ & N/A \\
\hline \multicolumn{9}{|l|}{ Immunology } \\
\hline $\mathrm{BT},{ }^{\circ} \mathrm{C}$ & 38.0 & 41.2 & $41.9^{d}$ & 38.2 & 38.3 & 37.4 & 37.3 & Afebrile \\
\hline WBC, /UL & $8700^{c}$ & 7300 & 7900 & 19600 & 8800 & 11100 & 3800 & 2800 \\
\hline Lymphocyte, /uL & $1260^{c}$ & 690 & 1910 & 590 & 440 & 1000 & 1220 & 1850 \\
\hline CRP, mg/dL & 15.98 & 2.95 & 0.68 & 0.33 & 0.79 & 1.55 & 0.4 & 0.49 \\
\hline Platelet, $\times 10^{3} / \mathrm{uL}$ & 190 & 184 & 100 & 72 & 83 & 220 & 242 & 310 \\
\hline D-dimer, ug/mL & 16.8 & 28 & $>100$ & 26.8 & 25.3 & $\mathrm{~N} / \mathrm{A}$ & $\mathrm{N} / \mathrm{A}$ & $\mathrm{N} / \mathrm{A}$ \\
\hline
\end{tabular}

$\mathrm{Cr}$ Creatine, BUN Blood urea nitrogen, RBC Red blood cell, HPF High-power field, B2MG Beta-2 microglobulin, $C K$ Creatine kinase, $P a O_{2}$ Partial pressure of oxygen, $\mathrm{FiO}_{2}$ Fraction of inspiratory oxygen, $B T$ Body temperature, WBC White blood cell, CRP C-reactive protein, N/A Not available, MV Mechanical ventilation, NC Nasal cannula

a Data by dipstick

bData by microscopy

'Data of second day of admission

${ }^{\mathrm{d}}$ Data of 7th day of admission

e Data of 12th day of admission

fData of $13 \mathrm{~h}$ day of admission 
with no hematuria. Chest CT without contrast showed ground-glass opacities with bilateral peripheral distribution and no pleural effusions. Patient was intubated and received mechanical ventilation, and piperacillintazobactam, azithromycin, methylprednisolone, and favipiravir were started empirically due to acute respiratory distress syndrome (ARDS). A SARS-CoV-2 PCR test was performed on hospital day five and returned positive. While the patient's respiratory condition improved gradually, his high fever still remained with no elevation of white blood cell count or CRP level. On the fifth day of hospitalization, risperidone administration was initiated for delirium. On hospital day eight, a significant increase in serum creatinine kinase accompanying brown colored urine was observed. Using dipstick urinalysis, 2+ proteinuria and $3+$ hematuria were detected. In microscopic urinalysis, a few red cells (1-4 RBCs/HPF), myoglobinuria (urine myoglobin concentration was 120,000 ng/ $\mathrm{mL}$ ), and massive granular casts were also detected. Risperidone was discontinued. On hospital day 11, the patient's serum creatinine was further elevated, although his urine volume was adequately maintained with no significant hypotension and volume depletion. Additionally, he suddenly presented microscopic hematuria with no dysmorphic RBCs (>50 RBCs/HPF). He was suspected of having heme pigment-associated ATN. His serum creatinine level gradually decreased (peaked at $8.13 \mathrm{mg} /$ $\mathrm{dL}$ on hospital day 16), with an eventual disappearance of microscopic hematuria and granular casts. Regarding the pneumonia, the patient discontinued mechanical ventilation on hospital day nine and was discharged on day 33 following two negative PCR tests. After discharge, his renal function recovered to basal level.

\section{Discussion and conclusions}

In this report, patient 1 was suspected of having vancomycin-associated AKI (VA-AKI) from the clinical course. Patient 2 was suspected of having heme pigment-induced AKI caused by rhabdomyolysis. Interestingly, both patients also developed microscopic hematuria at the occurrence of AKI (Table 3). It is not common to find microscopic hematuria in VA-AKI in addition to rhabdomyolysis. Additionally, patient 2 had elevated D-dimer and low platelet levels simultaneously at the same time as serum creatinine started to elevate (Table 2). Although platelet count and D-dimer level could be associated with severity and prognosis of patients with COVID-19 [6], these findings were observed in a COVID-19 patient with thrombotic microangiopathy that was diagnosed by kidney biopsy [7]. Recent studies have suggested that SARS-CoV-2 causes specific manifestations of proximal tubule dysfunction [8]. However, hematuria might not usually be detected in the patients with proximal tubular injury. Therefore, although
Table 3 Summary of two patients

\begin{tabular}{lll}
\hline & Patient 1 & Patient 2 \\
\hline Clinical characteristics & 77 & 45 \\
Age, year & Female & Male \\
Sex & None & None \\
Hypertension & None & None \\
Diabetes & None & None \\
Chronic kidney disease & None & None \\
Chronic obstructive pulmonary disease & 8 & 10 \\
Days from illness onset to admission, day & 8 & \\
Data of AKI & & 20 \\
Days from illness onset to AKI stage & 23 & $3+$ \\
3 onset, day & & $>50$ \\
Urine protein at onset of AKI stage 3 & $+/-$ & $5+$ \\
Urine RBC at onset of AKI stage 3, /HPF & $30-49$ \\
Urine granular cast & $4+$ & \\
Respiratory status & & 9 \\
Days from illness onset to MV start, day & 12 & 40 \\
Duration of MV, day & 40
\end{tabular}

AKI Acute kidney injury, RBC Red blood cell, HPF High-power field, RRT Renal replacement therapy, MV Mechanical ventilation

our patients did not undergo renal biopsy, they also could have accompanied renal microangiopathy.

A report on autopsy findings from deceased patients with COVID-19 has demonstrated the presence of severe injury of the endothelium in the kidney [9], and it is thought that COVID-19-associated microangiopathy may also contribute to the kidney damage [10]. In a few cohort studies of hospitalized COVID-19 patients, 26.7$48 \%$ of them had hematuria as detected by a dipstick [2, $4,11]$. Additionally, a study of 5449 patients who were hospitalized with COVID-19 also highlighted that 40.9\% of patients had microscopic hematuria (defined as red blood cells > 5) [1]. Furthermore, in some cohort studies of COVID-19, hematuria was one of the independent risk factors for in-hospital death [2], and elevated Ddimer and low platelet levels were correlated with even worse outcomes [12]. Based on these findings, it is speculated that these patients may have microangiopathy and could be vulnerable to developing severe AKI. In the present two patient cases, it is possible that this pathological background may have caused exaggerated tubular damage by vancomycin or heme pigment.

It is a known fact that critically ill patients are more susceptible to VA-AKI [13]. According to a study on 12,758 medical records in Hong Kong, 1450 patients were identified as VA-AKI, and logistic regression analysis showed that respiratory failure, piperacillin-tazobactam, and meropenem prescription were the risk factors significantly associated with VA-AKI [14]. In the patients with COVID-19, $3-17 \%$ developed ARDS $[15,16]$, and almost all critically 
Table 4 Case reports of rhabdomyolysis in COVID-19 patients

\begin{tabular}{|c|c|c|c|c|c|c|}
\hline $\begin{array}{l}\text { Age, } \\
\text { year }\end{array}$ & Sex & $\begin{array}{l}\text { Onset of rhabdomyolysis, } \\
\text { days }^{\text {a }}\end{array}$ & $\begin{array}{l}\text { Maximum value of } \\
\text { CK, U/L }\end{array}$ & $\begin{array}{l}\text { Maximum value of } \mathrm{Cr} \text {, } \\
\mathrm{mg} / \mathrm{dL}\end{array}$ & $\begin{array}{l}\text { Minimum value of } \mathrm{Cr} \text {, } \\
\mathrm{mg} / \mathrm{dL}\end{array}$ & Reference \\
\hline 88 & Male & 1 & 13581 & 1.38 & 1.09 & [20] \\
\hline 49 & Male & 7 & 23800 & 1.18 & 0.72 & [21] \\
\hline 60 & Male & 15 & 11842 & Normal & Normal & {$[22]$} \\
\hline 16 & Male & 5 & 457656 & 0.89 & 0.68 & [23] \\
\hline 37 & Male & 2 & 35000 & 5.0 (with RRT) & 2.0 & [24] \\
\hline 45 & Male & 17 & 79508 & 8.03 & 0.86 & $\begin{array}{l}\text { Patient } 2 \text { in this } \\
\text { report }\end{array}$ \\
\hline
\end{tabular}

CK Creatine kinase, $C r$ Creatinine, RRT Renal replacement therapy

${ }^{\mathrm{a}}$ After onset of COVID-19

ill patients received antibiotics $[17,18]$. Therefore, these patients could have a risk of VA-AKI, which suggests the risk of superimposed nephrotoxicity factors in the development of AKI. Additionally, COVID-19 patients may be susceptible to VA-AKI due to the proximal tubular damage caused by SARS-CoV-2.

In patient 2 , although the clinical symptoms could be descriptive of neuroleptic malignant syndrome [19], it is still possible that rhabdomyolysis may have been related to SARS-CoV-2 infection. A report of 1099 patients with COVID-19 in China highlighted that two patients had developed rhabdomyolysis [16]. There were five case reports of rhabdomyolysis in COVID-19 patients (Table 4) aged 16-88 years. All patients were male. Among the five patients, three developed AKI [20, 21, 24] and one of three patients received renal replacement therapy [24]. Different pathogeneses of rhabdomyolysis have been suggested; these include direct invasion of the muscle by virus, cytokine storm resulting in muscle damage, and muscle injury by circulating viral toxins [23]. These reports may well suggest the risk of superimposed nephrotoxicity factors in developing AKI as is also the case of antibiotics.

In the present two cases, the granular casts were detected in both patients at the onset of AKI (Table 3). A study of 267 AKI patients showed that the granular cast was a valuable diagnostic tool for confirming the diagnosis of ATN [25]. COVID-19 patients are thought to be susceptible to volume depletion and pre-renal AKI due to high fever and/or gastrointestinal losses. In a study of 333 hospitalized patients with COVID-19, 35 patients developed AKI and two of them were diagnosed with pre-renal AKI [11]. The management of ATN includes maintaining an optimal hemodynamic status to ensure

Table 5 Characteristics of the cohort studies analyzing hematuria in COVID-19 patients

\begin{tabular}{|c|c|c|c|c|c|c|c|c|c|}
\hline Study & $\begin{array}{l}\text { Inclusion } \\
\text { period }\end{array}$ & Institutions & Location & Population & $\begin{array}{l}\text { No. of } \\
\text { patients }\end{array}$ & $\begin{array}{l}\text { Median age, } \\
\text { years }\end{array}$ & $\begin{array}{l}\text { Male } \\
(\%)\end{array}$ & $\begin{array}{l}\text { Admitted in } \\
\text { ICU (\%) }\end{array}$ & $\begin{array}{l}\text { Mortality } \\
(\%)\end{array}$ \\
\hline $\begin{array}{l}\text { Xia et al. } \\
{[27]}\end{array}$ & $\begin{array}{l}\text { Feb 5-Mar } \\
20,2020\end{array}$ & Tongji Hospital & $\begin{array}{l}\text { Wuhan, } \\
\text { China }\end{array}$ & ICU & 81 & 66.6 & $\begin{array}{l}54 \\
(66.7)\end{array}$ & $81(100)$ & $60(74.1)$ \\
\hline $\begin{array}{l}\text { Hirsch } \\
\text { et al. [1] }\end{array}$ & $\begin{array}{l}\text { Mar 1-Apr 5, } \\
2020\end{array}$ & 13 hospitals & $\begin{array}{l}\text { New York, } \\
\text { USA }\end{array}$ & Hospitalized & 5449 & 64 & $\begin{array}{l}3317 \\
(60.9)\end{array}$ & 1395 (25.6) & ${ }_{a} 888(16.3)$ \\
\hline $\begin{array}{l}\text { Hong } \\
\text { et al. [28] }\end{array}$ & $\begin{array}{l}\text { Jan 16-Mar } \\
13,2020\end{array}$ & 2 hospitals & $\begin{array}{l}\text { Sichuan, } \\
\text { China }\end{array}$ & Hospitalized & 168 & 46.7 & $\begin{array}{l}92 \\
(54.2)\end{array}$ & N/A & $3(1.8)$ \\
\hline $\begin{array}{l}\mathrm{Na} \text { et al. } \\
\text { [29] }\end{array}$ & $\begin{array}{l}\text { Feb 1-Apr 24, } \\
2020\end{array}$ & $\begin{array}{l}\text { Chungnam National } \\
\text { University Hospital }\end{array}$ & $\begin{array}{l}\text { Daejeon, } \\
\text { Korea }\end{array}$ & Hospitalized & 66 & 45.6 & $\begin{array}{l}35 \\
(53.0)\end{array}$ & N/A & $0(0)$ \\
\hline $\begin{array}{l}\text { Cheng } \\
\text { et al. [2] }\end{array}$ & $\begin{array}{l}\text { Jan } 28-F e b \\
11,2020\end{array}$ & Tongji Hospital & $\begin{array}{l}\text { Wuhan, } \\
\text { China }\end{array}$ & Hospitalized & 701 & 63 & $\begin{array}{l}367 \\
(52.4)\end{array}$ & $73(10.4)$ & $113(16.1)$ \\
\hline $\begin{array}{l}\text { Chen } \\
\text { et al. [17] }\end{array}$ & $\begin{array}{l}\text { Jan } 13-\text { Feb } \\
12,2020\end{array}$ & Tongji Hospital & $\begin{array}{l}\text { Wuhan, } \\
\text { China }\end{array}$ & Hospitalized & 799 & 68 & $\begin{array}{l}171 \\
(62)\end{array}$ & N/A & ${ }_{b}^{113(14.1)}$ \\
\hline $\begin{array}{l}\text { Taher } \\
\text { et al. [30] }\end{array}$ & $\begin{array}{l}\text { Apr 1-May } \\
31,2020\end{array}$ & $\begin{array}{l}\text { Salmaniya Medical } \\
\text { Complex }\end{array}$ & $\begin{array}{l}\text { Manama, } \\
\text { Bahrain }\end{array}$ & Hospitalized & 73 & 54 & $\begin{array}{l}44 \\
(60.3)\end{array}$ & $23(31.5)$ & $13(17.8)$ \\
\hline $\begin{array}{l}\text { Pei et al. } \\
\text { [11] }\end{array}$ & $\begin{array}{l}\text { Jan 28-Feb 9, } \\
2020\end{array}$ & Tongji Hospital & $\begin{array}{l}\text { Wuhan, } \\
\text { China }\end{array}$ & Hospitalized & 333 & 56.3 & $\begin{array}{l}182 \\
(54.7)\end{array}$ & N/A & $29(8.7)$ \\
\hline Li et al. [4] & $\begin{array}{l}\text { Jan 6-Feb 21, } \\
2020\end{array}$ & Tongji Hospital & $\begin{array}{l}\text { Wuhan, } \\
\text { China }\end{array}$ & Hospitalized & 193 & 57 & $95(49)$ & N/A & $32(17)^{c}$ \\
\hline
\end{tabular}

ICU Intensive care unit, N/A Not available

${ }^{\mathrm{a}} 1281$ patients were still admitted at publication

${ }^{b} 525$ patients were still admitted at publication

' 66 patients were still admitted at publication 
Table 6 Hematuria and proteinuria in COVID-19 patients

\begin{tabular}{|c|c|c|c|c|c|}
\hline Study & Hematuria (\%) & Definition of hematuria & Proteinuria (\%) & Definition of proteinuria & Timing of urinalysis \\
\hline Xia et al. [27] & $10(27.8)^{a}$ & $>2+$ by dipstick & $5(13.9)^{a}$ & $>2+$ by dipstick & At hospital presentation \\
\hline Hirsch et al. [1] ${ }^{b}$ & $249(40.9)$ & $\mathrm{RBCs}>5 / \mathrm{HPF}$ & $272(42.1)^{c}$ & $\geq 2+$ by dipstick ${ }^{c}$ & $24 \mathrm{~h}$ before or $48 \mathrm{~h}$ after $\mathrm{AKI}$ \\
\hline Hong et al. [28] & $18(17.5)^{d}$ & $\geq 1+$ by dipstick & $19(18.4)^{d}$ & $\geq 1+$ by dipstick & N/A \\
\hline Na et al. [29] & $10(15.2)$ & $\mathrm{RBC} s>3 / \mathrm{HPF}$ & $9(13.6)$ & Trace or + by dipstick & During hospitalization \\
\hline Cheng et al. [2] & $118(26.7)^{\mathrm{e}}$ & $\geq 1+$ by dipstick & $194(43.9)^{\mathrm{e}}$ & $\geq 1+$ by dipstick & N/A \\
\hline Chen et al. [17] & $84(50.6)^{f}$ & N/A & $100(60.2)^{f}$ & N/A & N/A \\
\hline Taher et al. [30] & $15(20.5)$ & $\geq 1+$ by dipstick & $38(52.1)$ & $\geq 1+$ by dipstick & N/A \\
\hline Pei et al. [11] & $139(41.7)$ & $\geq$ Trace by dipstick & $219(65.8)$ & $\geq$ Trace by dipstick & On the first morning after admission \\
\hline Li et al. [4] & $71(48.3)^{g}$ & $\geq$ Trace by dipstick & $88(59.9)$ & $\geq$ Trace by dipstick & Upon admission \\
\hline
\end{tabular}

RBCs Red blood cells, HPF High-power field, N/A Not available

${ }^{a}$ Only 36 patients were tested

${ }^{b}$ Only AKI patients were included

'Up to 646 of 1993 AKI patients were tested

${ }^{\mathrm{d}}$ Only 103 patients were tested

${ }^{\mathrm{e}}$ Only 442 patients were tested

fOnly 166 patients were tested

${ }^{g}$ Only 147 patients were tested

renal perfusion. In COVID-19 patients with ARDS, conservative fluid management is recommended [26]. Therefore, urine sediment examination may be a useful tool to make a precise diagnosis and appropriately manage AKI in COVID-19 patients.

The etiology of AKI in patients with COVID-19 is multifactorial. Superimposition of nephrotoxin(s) and virus-associate intra-renal microangiopathy may be a crucial trigger of kidney injury leading to severe AKI in COVID-19 patients. Therefore, in COVID-19 patients, risk factors for AKI should be taken into consideration to prevent its progression into severe AKI.

\section{Literature review}

Nine cohort studies were performed to investigate hematuria in COVID-19 patients (Table 5). Four studies were reported from the same hospital, i.e., Tongji Hospital, Wuhan, China [2, 4, 11, 17, 27]. In nine studies, one study analyzed the patients admitted in the intensive care unit (ICU) [27], and the other studies examined all hospitalized patients $[1,2,4,11,17,28-30]$. The median age ranged from 40 to 60 years. Almost half of the patients were male. In three studies involving the hospitalized patients, $10-30 \%$ were in the ICU $[1,2,30]$. The mortality rate ranged from 0 to $70 \%$. Older cohorts tended to have higher mortality rates $[1,2,17]$.

The prevalence of hematuria and proteinuria is shown in Table 6. One study evaluated only AKI patients [1]. In three studies, urinalysis was performed upon admission $[4,11,27]$. In four studies, the timing of the urinalysis was unknown $[2,17,28,30]$. In all studies, hematuria was observed in approximately $15-50 \%$ patients. Six studies detected hematuria using the urine dipstick test $[2,4,11,27,28,30]$, and only two studies used urine sediment examination [1, 29]. Approximately 10-60\% patients had proteinuria. Eight studies detected proteinuria using the urine dipstick test $[1,2,4,11,27-30]$. In these nine studies, four studies examined the rates of hematuria and proteinuria in AKI patients with COVID19 (Table 7). The incidence of AKI ranged from 10 to $50 \%$, of which $5-9 \%$ required dialysis support $[1,27,30]$. Hematuria was detected in $30-60 \%$ of the AKI patients.

Table 7 Hematuria and proteinuria in AKI patients with COVID-19

\begin{tabular}{llllll}
\hline Study & AKI (\%) $^{\mathbf{a}}$ & Dialysis support (\%) & Hematuria $^{\mathbf{b}}$ in AKI (\%) & Proteinuria $^{\mathbf{b}}$ in AKI (\%) & Timing of urinalysis $^{\text {in }}$ \\
\hline Xia et al. [27] & $41(50.6)$ & $8(9.9)$ & $6(31.6)^{c}$ & $3(15.8)^{b}$ & At hospital presentation \\
Hirsch et al. [1] & $1993(36.6)$ & $285(5.2)$ & $249(40.9)^{d}$ & $272(42.1)^{d}$ & $24 \mathrm{~h}$ before or $48 \mathrm{~h}$ after AKl \\
Taher et al. [30] & $29(39.7)$ & $7(9.6)$ & $11(37.9)$ & $24(82.8)$ & N/A \\
Pei et al. [11] & $35(10.5)$ & N/A & $21(60.0)$ & $31(88.6)$ & On the first morning after admission \\
\hline
\end{tabular}

AKI Acute kidney injury, RBCs Red blood cells, HPF High-power field, N/A Not available, KDIGO Kidney Disease: Improving Global Outcomes

${ }^{a} A K I$ definition was based on KDIGO criteria [31]

${ }^{\mathrm{b}}$ Definition is shown in Table 6

cOnly 19 AKI patients were tested

dUp to 646 of 1993 AKI patients were tested 
Approximately $20-80 \%$ of AKI patients had proteinuria. All studies used the dipstick to detect proteinuria.

The pathophysiology of hematuria and proteinuria in COVID-19 patients remains unclear. Sharma et al. evaluated biopsied kidneys from ten COVID-19 patients with AKI [32]. In their study, all patients had proteinuria and were diagnosed with acute tubular necrosis through kidney biopsy. Interestingly, one patient with massive hematuria (>50 RBCs/HPF) was also diagnosed with thrombotic microangiopathy. Furthermore, in another study that evaluated biopsy samples of native kidneys from 14 patients with COVID-19, five patients were diagnosed with collapsing glomerulopathy [33]. These studies suggested that COVID-19 affected the kidneys in the tubular, vascular, and glomerular compartments [32].

\section{Abbreviations \\ AKI: Acute kidney injuryCOVID-19Coronavirus disease in 2019SARS-CoV- 2Severe acute respiratory syndrome coronavirus 2CRPC-Reactive proteinRBCs/HPFRed blood cells per high-power fieldATNAcute tubular necrosisARDSAcute respiratory distress syndromeVA-AKIVancomycin- associated AKI}

\section{Acknowledgements}

Not applicable.

\section{Authors' contributions}

$T F, K W, Y I, F T$, and both $M N$ participated in the literature review. TF, KS, and $\mathrm{TH}$ carried out the data collection and drafting. TF, KW, and YI wrote the manuscript. SI, TH, NO, FT, and both $\mathrm{MN}$ were involved in the final editing and reviewing. All of the authors were actively involved in the clinical care of the patients. The authors read and approved the final manuscript.

\section{Funding}

None.

\section{Availability of data and materials}

All data generated or analyzed during this study are included in this published article.

\section{Ethics approval and consent to participate}

Not applicable.

\section{Consent for publication}

Written informed consent was obtained from both patients for the publication of this case report.

\section{Competing interests}

The authors declare that they have no competing interests.

\section{Author details}

'Department of Nephrology, St. Luke's International Hospital, 9-1 Akashi-cho, Chuo-ku, Tokyo 104-8560, Japan. ${ }^{2}$ Department of Emergency and Critical Care Medicine, St. Luke's International Hospital, 9-1 Akashi-cho, Chuo-ku, Tokyo 104-8560, Japan.

Received: 19 August 2020 Accepted: 23 November 2020

Published online: 04 December 2020

\section{References}

1. Hirsch JS, Ng JH, Ross DW, Sharma P, Shah HH, Barnett RL, et al. Acute kidney injury in patients hospitalized with COVID-19. Kidney Int. 2020;98: 209-18.

2. Cheng $Y$, Luo R, Wang K, Zhang M, Wang Z, Dong L, et al. Kidney disease is associated with in-hospital death of patients with COVID-19. Kidney Int. 2020;97:829-38.
3. Xiao G, Hu H, Wu F, Sha T, Huang Q, Li H, et al. Acute kidney injury in patients hospitalized with COVID-19 in Wuhan, China: a single-center retrospective observational study. medRxiv. 2020. https://doi.org/10.1101/ 2020.04.06.20055194.

4. Li Z, Wu M, Yao J, Guo J, Liao X, Song S, et al. Caution on kidney dysfunctions of COVID-19 patients. medRxiv. 2020. https://doi.org/10.1101/ 2020.02.08.20021212

5. Sise ME, Baggett MV, Shepard J-AO, Stevens JS, Rhee EP. Case 17-2020: A 68-year-old man with Covid-19 and acute kidney injury. N Engl I Med. 2020; 382:2147-56.

6. Liao D, Zhou F, Luo L, Xu M, Wang H, Xia J, et al. Haematological characteristics and risk factors in the classification and prognosis evaluation of COVID-19: a retrospective cohort study. Lancet Haematol. 2020;7:e671-8.

7. Jhaveri KD, Meir LR, Flores Chang BS, Parikh R, Wanchoo R, Barilla-LaBarca ML, et al. Thrombotic microangiopathy in a patient with COVID-19. Kidney Int. 2020;98:509-12.

8. Werion A, Belkhir L, Perrot M, Schmit G, Aydin S, Chen Z, et al. SARS-CoV-2 causes a specific dysfunction of the kidney proximal tubule. Kidney Int. 2020. https://doi.org/10.1016/j.kint.2020.07.019.

9. Su H, Yang M, Wan C, Yi L-X, Tang F, Zhu H-Y, et al. Renal histopathological analysis of 26 postmortem findings of patients with COVID-19 in China. Kidney Int. 2020;98:219-27.

10. Batlle $D$, Soler MJ, Sparks MA, Hiremath S, South AM, Welling PA, et al. Acute kidney injury in COVID-19: emerging evidence of a distinct pathophysiology. J Am Soc Nephrol. 2020;31:1380-3.

11. Pei G, Zhang Z, Peng J, Liu L, Zhang C, Yu C, et al. Renal involvement and early prognosis in patients with COVID-19 pneumonia. J Am Soc Nephrol. 2020;31:1157-65.

12. Tang N, Li D, Wang $X$, Sun Z. Abnormal coagulation parameters are associated with poor prognosis in patients with novel coronavirus pneumonia. J Thromb Haemost. 2020;18:844-7.

13. Elyasi S, Khalili H, Dashti-Khavidaki S, Mohammadpour A. Vancomycininduced nephrotoxicity: mechanism, incidence, risk factors and special populations. A literature review. Eur J Clin Pharmacol. 2012;68:1243-55.

14. Qin X, Tsoi M-F, Zhao X, Zhang L, Qi Z, Cheung BMY. Vancomycinassociated acute kidney injury in Hong Kong in 2012-2016. BMC Nephrol. 2020;21:41.

15. Chen N, Zhou M, Dong X, Qu J, Gong F, Han Y, et al. Epidemiological and clinical characteristics of 99 cases of 2019 novel coronavirus pneumonia in Wuhan, China: a descriptive study. Lancet (London, England). 2020;395:507-13.

16. Guan W, Ni Z, Hu Y, Liang W, Ou C, He J, et al. Clinical characteristics of coronavirus disease 2019 in China. N Engl J Med. 2020:382:1708-20.

17. Chen T, Wu D, Chen H, Yan W, Yang D, Chen G, et al. Clinical characteristics of 113 deceased patients with coronavirus disease 2019: retrospective study. BMJ. 2020;368:m1091.

18. Zhou F, Yu T, Du R, Fan G, Liu Y, Liu Z, et al. Clinical course and risk factors for mortality of adult inpatients with COVID-19 in Wuhan, China: a retrospective cohort study. Lancet (London, England). 2020; 395:1054-62.

19. Soh M, Hifumi T, Isokawa S, Shimizu M, Otani N, Ishimatsu S. Neuroleptic malignant syndrome in patients with COVID-19. Am J Emerg Med. 2020. https://doi.org/10.1016/j.ajem.2020.05.042.

20. Suwanwongse K, Shabarek N. Rhabdomyolysis as a presentation of 2019 novel coronavirus disease. Cureus. 2020. https://doi.org/10.7759/cureus.7561.

21. Mukherjee A, Ghosh R, Aftab G. Rhabdomyolysis in a patient with coronavirus disease 2019. Cureus. 2020. https://doi.org/10.7759/cureus.8956.

22. Jin $\mathrm{M}$, Tong $\mathrm{Q}$. Rhabdomyolysis as potential late complication associated with COVID-19. Emerg Infect Dis. 2020;26:1618-20.

23. Gefen AM, Palumbo N, Nathan SK, Singer PS, Castellanos-Reyes L, Sethna CB. Pediatric COVID-19-associated rhabdomyolysis: a case report. Pediatr Nephrol. 2020;35:1517-20.

24. Chong WH, Saha B. Severe acute respiratory syndrome coronavirus 2 (SARSCoV-2) associated with rhabdomyolysis and acute kidney injury (AKI). Am J Med Sci. 2020. https://doi.org/10.1016/j.amjms.2020.07.032.

25. Perazella MA, Coca SG, Kanbay M, Brewster UC, Parikh CR. Diagnostic value of urine microscopy for differential diagnosis of acute kidney injury in hospitalized patients. Clin J Am Soc Nephrol. 2008:3:1615-9.

26. Matthay MA, Aldrich JM, Gotts JE. Treatment for severe acute respiratory distress syndrome from COVID-19. Lancet Respir Med. 2020;8:433-4.

27. Xia P. Wen Y, Duan Y, Su H, Cao W, Xiao M, et al. Clinicopathological features and outcomes of acute kidney injury in critically III COVID-19 with 
prolonged disease course: a retrospective cohort. J Am Soc Nephrol. 2020; 31:2205-21.

28. Hong D, Long L, Wang AY, Lei Y, Tang Y, Zhao JW, et al. Kidney manifestations of mild, moderate and severe coronavirus disease 2019: a retrospective cohort study. Clin Kidney J. 2020;13:340-6.

29. Na KR, Kim HR, Ham Y, Choi DE, Lee KW, Moon JY, et al. Acute kidney injury and kidney damage in COVID-19 patients. J Korean Med Sci. 2020;35:e257.

30. Taher A, Alalwan AA, Naser N, Alsegai O, Alaradi A. Acute kidney injury in COVID-19 pneumonia: a single-center experience in Bahrain. Cureus. 2020; 12:e9693.

31. Kellum JA, Lameire N, Aspelin P, Barsoum RS, Burdmann EA, Goldstein SL, et al. Notice. Kidney Int Suppl. 2012;2:1.

32. Sharma P, Uppal NN, Wanchoo R, Shah HH, Yang Y, Parikh R, et al. COVID19-associated kidney injury: a case series of kidney biopsy findings. J Am Soc Nephrol. 2020:31:1948-58.

33. Kudose S, Batal I, Santoriello D, Xu K, Barasch J, Peleg Y, et al. Kidney biopsy findings in patients with COVID-19. J Am Soc Nephrol. 2020;31:1959-68.

\section{Publisher's Note}

Springer Nature remains neutral with regard to jurisdictional claims in published maps and institutional affiliations.

Ready to submit your research? Choose BMC and benefit from:

- fast, convenient online submission

- thorough peer review by experienced researchers in your field

- rapid publication on acceptance

- support for research data, including large and complex data types

- gold Open Access which fosters wider collaboration and increased citations

- maximum visibility for your research: over $100 \mathrm{M}$ website views per year

At BMC, research is always in progress.

Learn more biomedcentral.com/submissions 